ISSN 0258-7122

Bangladesh J. Agril. Res. 33(3) : 579-585, December 2008

\title{
EFFECT OF POSTHARVEST TREATMENTS ON SHELF LIFE AND QUALITY OF TOMATO
}

\author{
T.A.A. NASRIN ${ }^{1}$, M.M. MOLLA ${ }^{2}$ M. AlAMGIR HOSSAEN ${ }^{3}$, \\ M. S. ALAM ${ }^{4}$ AND L. YASMIN ${ }^{5}$
}

\begin{abstract}
An experiment was conducted to study the effect of chlorine, packaging and storage conditions on quality and shelf life of tomato. Tomato treated with chlorine; packed in perforated (0.25\%) polyethylene bag and kept at ambient (Temperature $20-25^{\circ} \mathrm{C} \&$ relative humidity $70-90 \%$ ) condition resulted in substantial reduction in losses caused by decay and weight loss. This treatment combination also considerably delayed compositional changes in TSS, total sugar, reducing sugar, vitamin-C, B-carotene, etc. Under this condition, shelf life of tomato had extended upto 17 days as compared to non-treated and kept in ambient condition without packaging or packed in gunny bag for 7 days only.
\end{abstract}

Key Words: Postharvest treatments, shelf-life, quality of tomato.

\section{Introduction}

Tomato (Lycopersicon esculentum) is one of the most important supplementary sources of minerals and vitamins in human diet. The estimated annual production of tomato in Bangladesh was 119935 MT in 2003-2004 (BBS, 2004). A loss of $50 \%$ between harvesting, transportation and consumption of fresh tomato has been reported by Aworth and Olorunda (1981). Since tomato is highly perishable, it encounters several problems in its transportation, storage and marketing (Ruth Ben et al., 1986). Owing to lack of information on appropriate postharvest treatments, packaging, temperature, etc, the fruits not only lose their quality but also encounter a substantial postharvest loss. The research efforts have helped to increase the production of tomato but the purpose of obtaining maximum profit will be served only if the increased production is supplemented with the similar efforts to minimize the postharvest losses and enhance the shelf life. In many countries of the world, fruits and vegetables are washed in chlorine or potassium permanganate before packaging (Giraldo et al., 1977). It is done in order to reduce micro flora, especially bacteria from the produce. Chlorine water is achieved by adding 200 ppm sodium hypochlorite in clean water (Amiruzzaman, 2000).

Modified atmosphere packaging is used in the storage of fresh fruits and vegetables; the term refers to their storage in plastic films, which restrict the transmission of respiratory gases. This results in the accumulation of carbon

\footnotetext{
${ }^{1 \& 2}$ Scientific Officer, ${ }^{3}$ Senior Scientific Officer, Postharvest Technology Section, ${ }^{4}$ Scientific Officer, Plant Physiology Section, ${ }^{5}$ Scientific Officer, Plant Physiology Section, HRC, BARI, Joydebpur, Gazipur-1701, Bangladesh.
} 
dioxide and depletion of oxygen around the crop, which may increase their storage life (Kader et al., 1989). Badgujar et al., (1987) reported that packing of brinjal in perforated polyethylene bags (1\% holes) prolonged shelf life and maintained quality compared to unpacked fruit.

It was shown in different observation trials that tomato showed better performance in perforated polyethylene bags $(0.25 \%$ holes $)$. So, the experiment was undertaken to study the effect of chlorine, packaging and storage conditions on quality and shelf life of tomato.

\section{Materials and Method}

Freshly harvested tomato Lalima (light pink colour) was obtained from Olericulture Division, Horticulture Research Centre, BARI, Joydebpur, Gazipur. This research was conducted at the laboratory of Postharvest Technology Section, HRC, BARI, during March 2007. The fruits were sorted out to eliminate bruised, punctured and damaged ones. The experiment was laid out in CRD factorial with three replications. There were three factors-A) Fruits were dipped in 200ppm chlorine solution for 5 minutes and spread on floor. It has two levels (chlorine treated and non-treated), B) storage condition with two levels (ambient condition: Temperature $20-25^{\circ} \mathrm{C} \&$ relative humidity $70-90 \%$ and refrigerator: $4-5^{\circ} \mathrm{C} \&$ relative humidity $60-65 \%$ ) and C) packaging technique with three levels (without packaging/control, gunny bag, perforated polyethylene bag: $0.0125 \mathrm{~mm}$ thick and $0.25 \%$ holes). Each replication of the treatments is consisted of $0.5 \mathrm{~kg}$ fruit. Data on physiological weight loss (\%), decay (\%), non-marketability (\%), shelf life (days), acidity (\%), total soluble solid (TSS), reducing sugar (\%), total sugar (\%), vitamin-C (mg/ bog) and B-carotene (mg/ 100g) were recorded. Physiological weight loss (\%), decay (\%) and marketability (\%) data were recoded at 4 days interval. Acidity (\%), total soluble solid (TSS), reducing sugar (\%), total sugar (\%), vitamin-C (mg/ 100g) and Bcarotene (mg/ 100g) were recorded at first and at the last days of storage period.

Physiological weight loss (\%) : It was determined by periodical weighing of fruits and expressed as percentage of original weight. Damaged (rotting or chilling injury) fruits were also included with it.

Decay (\%): The fruits were observed visually for rotting and microbial infection.

Shelf life (day): The shelf life is a period of time which starts from harvesting and extends upto the start of rotting of fruits (Mondal, 2000).

Chemical analysis: Acidity, TSS, reducing sugar, total sugar, vitamin-C and Bcarotene were determined at initial and at the last day of storage period. Reducing sugar and total sugar were determined by Lane and Eynon Method, TSS by using refractometer, acidity by treating against standard $\mathrm{NaOH}$ solution, ascorbic acid by 2, 6- Diclorophenol-Indophenol Visual Titration Method and B -carotene by AOAC (1975) method. All these chemical analysis methods were conducted according to Rangana (1986). 


\section{Results and Discussion}

Data on weight loss (\%) and non-marketability (\%) of tomato were analyzed at 20th and 40th day of storage period. Since the combined effect of chlorine, storage condition and packaging was slgnificant in all cases, only combined effect was described for interpretation of results as shown in Table 1.

Physiological Weight loss (\%): At 20th day of storage period, tomato treated with chlorine, packed in perforated polyethylene bag and kept in refrigerator showed minimum weight loss (4.9\%) followed by $(7.49 \%)$ when those were non treated, packed in perforated polyethylene bag and kept in refrigerator are statistically similar. On the other hand, tomato showed maximum (88.7\%) weight loss when those were non- treated and kept in refrigerator without packaging, followed by $(81.7 \%)$ when treated with chlorine, packed in gunny bag and kept in refrigerator due to chilling injury. Here non-marketable fruits are also including in weight loss.

Table 1. Combined effect of chlorine, storage condition and packaging on post harvest life of tomato.

\begin{tabular}{|c|c|c|c|c|c|}
\hline Treatment & Shelf life & \multicolumn{2}{|c|}{ \% Weight loss } & \multicolumn{2}{|c|}{ \% Non-marketable } \\
\hline $\mathrm{A}_{1} \mathrm{~B}_{1} \mathrm{C}_{1}$ & $7 \mathrm{~g}$ & $\begin{array}{l}\text { 20th day } \\
38.03 c \\
(39.95)\end{array}$ & $\begin{array}{l}\text { 40th day } \\
\text { 100a (85.86) }\end{array}$ & $\begin{array}{l}\text { 20th day } \\
34.82 \mathrm{c} \\
\text { (34.510 }\end{array}$ & $\begin{array}{l}\text { 40tl day } \\
\text { 100a (85.73) }\end{array}$ \\
\hline $\mathrm{A}_{1} \mathrm{~B}_{1} \mathrm{C}_{2}$ & $7 \mathrm{~g}$ & $\begin{array}{l}39.66 \mathrm{c} \\
(37.61)\end{array}$ & 100a (85.86) & $\begin{array}{l}30.36 c \\
(32.18)\end{array}$ & 100a (85.73) \\
\hline $\mathrm{A}_{1} \mathrm{~B}_{1} \mathrm{C}_{3}$ & 11de & $\begin{array}{l}\text { 15.2lde } \\
\text { (22.10) }\end{array}$ & $\begin{array}{l}87.4 \mathrm{~cd} \\
(69.18)\end{array}$ & $\begin{array}{l}14.49 \mathrm{~d} \\
(21.55)\end{array}$ & $\begin{array}{l}89.99 \mathrm{~cd} \\
(67.36)\end{array}$ \\
\hline $\mathrm{A}_{1} \mathrm{~B}_{2} \mathrm{C}_{1}$ & 9f & 88.7a (63.47) & 100a (85.86) & $\begin{array}{l}88.89 a \\
(60.06)\end{array}$ & 100a (85.73) \\
\hline $\mathrm{A}_{1} \mathrm{~B}_{2} \mathrm{C}_{2}$ & 11de & $\begin{array}{l}\text { 79.22ab } \\
(55.09)\end{array}$ & 100a (85.86) & $\begin{array}{l}69.05 a b \\
(50.93)\end{array}$ & 100a (85.73) \\
\hline $\mathrm{A}_{1} \mathrm{~B}_{2} \mathrm{C}_{3}$ & 13bc & $\begin{array}{l}7.49 \mathrm{ef} \\
\text { (16.39) }\end{array}$ & $\begin{array}{l}\text { 89.34bcd } \\
\text { (71.17) }\end{array}$ & 4.78e (7.78) & $\begin{array}{l}\text { 84.13bcd } \\
(69.26)\end{array}$ \\
\hline $\mathrm{A}_{2} \mathrm{~B}_{1} \mathrm{C}_{1}$ & I2cd & $\begin{array}{l}21.78 d \\
(26.82)\end{array}$ & $\begin{array}{l}91.14 a b c \\
\text { (76) }\end{array}$ & $\begin{array}{l}13.69 d \\
(20.94)\end{array}$ & $\begin{array}{l}90.14 a b c \\
(74.33)\end{array}$ \\
\hline $\mathrm{A}_{2} \mathrm{~B}_{1} \mathrm{C}_{2}$ & 10ef & $\begin{array}{l}29.03 \mathrm{~cd} \\
\text { (31.37) }\end{array}$ & $\begin{array}{l}92.07 \mathrm{ab} \\
(81.02)\end{array}$ & $\begin{array}{l}19.45 \mathrm{~cd} \\
(25.15)\end{array}$ & $\begin{array}{l}68.79 \mathrm{ab} \\
(80.35)\end{array}$ \\
\hline $\mathrm{A}_{2} \mathrm{~B}_{1} \mathrm{C}_{3}$ & $17 \mathrm{a}$ & $\begin{array}{l}16.99 \mathrm{de} \\
(23.48)\end{array}$ & $\begin{array}{l}53.16 \mathrm{e} \\
(4)\end{array}$ & $\begin{array}{l}15.08 d \\
(22.04)\end{array}$ & $\begin{array}{l}54.76 \mathrm{e} \\
(46.05)\end{array}$ \\
\hline $\mathrm{A}_{2} \mathrm{~B}_{2} \mathrm{C}_{1}$ & 9f & $70.3 b(53.05)$ & 100a (85.86) & $\begin{array}{l}60.71 \mathrm{~b} \\
(49.38)\end{array}$ & $100 \mathrm{a}(85.73)$ \\
\hline $\mathrm{A}_{2} \mathrm{~B}_{2} \mathrm{C}_{2}$ & $12 \mathrm{~cd}$ & $\begin{array}{l}81.7 \mathrm{ab} \\
(57.32)\end{array}$ & 100a (85.86) & $\begin{array}{l}\text { 68.45ab } \\
(54.38)\end{array}$ & $\begin{array}{l}100 a \\
(85.73)\end{array}$ \\
\hline $\mathrm{A}_{2} \mathrm{~B}_{2} \mathrm{C}_{3}$ & $14 \mathrm{~b}$ & $4.9 f(12.31)$ & $\begin{array}{l}80.16 \mathrm{~d} \\
(63.35)\end{array}$ & $0.31 \mathrm{e}(0.97)$ & $79.96 \mathrm{dj}$ \\
\hline $\begin{array}{l}\text { Level of } \\
\text { Significance }\end{array}$ & ** & * & $*$ & $*$ & $* *$ \\
\hline $\mathrm{CV}(\%)$ & 3.5 & 14.04 & 7.37 & 18 & 8.28 \\
\hline
\end{tabular}

$\mathrm{A} 1=$ Non treated, $\mathrm{A} 2=$ Chlorine treated

$\mathrm{B} 1=$ Ambient condition B2= Refrigerator

C1= Without packaging, C2= Gunny bag, C3= Perforated polyethylene bag

Means with the same letter are not significantly different at 5\% level by DMRT

Figures in parthesis indicate the transform value of the original

NS $=$ Not significant, $*=$ Significant at $5 \%$ level, $* *=$ significant at $1 \%$ level 
At 40th day of storage period, tomato treated with chlorine packed in perforated polyethylene bag and kept at ambient condition showed minimum weight loss (53.17\%). Besides that, other treatments lost their weight more than $80 \%$ which were not actually at marketable condition.

Shelf life(Day): Tomato treated with chlorine, packed in perforated polyethylene bag and kept at ambient condition had the maximum (17 days) shelf life, followed by I4 days in the fruits treated with chlorine, packed in perforated polyethylene bag and kept in refrigerator. Because perforated polyethylene .bag created a modified atmosphere by increasing $\mathrm{CO}_{2}$ and decreasing $\mathrm{O}_{2}$. Chlorine treatment also reduced the microbial load and thus extends shelf life. On the other hand, non-treated tomato kept in ambient condition without packaging or packed in gunny bag showed the minimum (7days) shelf life.

Decay (\%): Among all treatments, tomato became non-marketable due to disease incidence except those without packaging or packed in gunny bag kept in refrigerator damaged by chilling injury.

Marketability (\%): At 20th day of storage period, tomato packed in perforated polyethylene bag and kept in refrigerator and treated with chlorine showed the minimum $(0.31 \%)$ non-marketable fruits followed by $4.78 \%$ in non- treated. On the other hand, maximum (88.89\%) non marketable fruits were found in refrigerator, while it was non- treated and without packaging.

At $40^{\text {th }}$ day of storage period, among all treatments, only $54.76 \%$ tomato was non-marketable when treated with chlorine, packed in perforated polyethylene bag and kept at ambient condition. In all other treatments, more than $70 \%$ tomato were non-marketable at the same time.

Table 2 shows chemical composition of tomato (Lalima), which was analyzed for TSS, acidity, reducing sugar, total sugar; 13-carotene and Vitamin$\mathrm{C}$ at the initial stage and at the last day of storage period (days). Initially, TSS of tomato was $4.1 \%$, while final TSS was 3.14 to $3.96 \%$, which supports the findings of Salunkhe (1991). Changes of TSS were lower in fruits packed in perforated polyethylene bag than others. Initial acidity of tomato was $0.54 \%$ and during storage it was also reduced slightly, irrespective of different treatments. Initial total sugar and reducing sugar were $4.35 \%$ and $2.9 \%$, respectively. After storage, reducing sugar was reduced slightly ranging from 1 to $1.79 \%$. On the other hand, after storage, total sugar was decreased or increased slightly ranging from 3.9 to $4.5 \%$. It may be due to chemical impurities or personal error. Bcarotene of tomato was $4.16 \mathrm{mg} / 100 \mathrm{~g}$ initially and during storage period, it was increased ranging from $4.1 \mathrm{mg} / 100 \mathrm{~g}$ to $5.37 \mathrm{mg} / 100 \mathrm{~g}$. Because, pink colour tomato (initial stage) turns into red ripe stage during storage and this results also satisfy the findings of Salunkhe (1991). It is shown from Table 2 that during storage, B-carotene was higher when tomato packed in perforated polyethylene 
bag. Initially tomato contained $12.3 \mathrm{mg} / 100 \mathrm{~g}$ Vitamin-C, but at the last day of storage period, it was reduced significantly. The maximum and minimum values were found to be $4.1 \mathrm{mg} / 100 \mathrm{~g}$ and $5.3 \mathrm{mg} / 100$, respectively. It is shown from the Table 2 that Vitamin-C, was reduced in small amount when fruits were packed in perforated polyethylene bag and kept in refrigerator. These chemical compositions and changing behaviour of its after storage are supported by the findings of Salunkhe (1991).

Table 2. Chemical and nutritional changes of tomato during storage.

\begin{tabular}{|c|c|c|c|c|c|c|c|c|c|c|c|c|}
\hline \multirow[t]{2}{*}{ Treatment } & \multicolumn{2}{|c|}{$\mathrm{TSS}\left({ }^{0} \mathrm{Brix}\right)$} & \multicolumn{2}{|c|}{$\begin{array}{c}\text { Acidity } \\
(\%)\end{array}$} & \multicolumn{2}{|c|}{$\begin{array}{l}\text { Reducing } \\
\text { sugar (\%) }\end{array}$} & \multicolumn{2}{|c|}{$\begin{array}{l}\text { Total } \\
(\%)\end{array}$} & \multicolumn{2}{|c|}{$\begin{array}{l}\beta \text {-carotene } \\
(\mathrm{mg} / 100 \mathrm{~g})\end{array}$} & \multicolumn{2}{|c|}{$\begin{array}{l}\text { Vitamin-C } \\
(\mathrm{mg} / 100 \mathrm{~g})\end{array}$} \\
\hline & Initial & final & Initial & final & Initial & final & Initial & final & Initial & final & Initial & final \\
\hline $\mathrm{A}_{1} \mathrm{~B}_{1} \mathrm{C}_{1}$ & 4.1 & 3.97 & 0.54 & 0.14 & 2.9 & 1.03 & 4.35 & 4.3 & 4.16 & 4.23 & 12.3 & 4.2 \\
\hline $\mathrm{A}_{1} \mathrm{~B}_{1} \mathrm{C}_{2}$ & 4.1 & 3.31 & 0.54 & 0.19 & 2.9 & 1.0 & 4.35 & 4.2 & 4.16 & 4.51 & 12.3 & 4.1 \\
\hline $\mathrm{A}_{1} \mathrm{~B}_{1} \mathrm{C}_{3}$ & 4.1 & 3.75 & 0.54 & 0.25 & 2.9 & 1.4 & 4.35 & 4.32 & 4.16 & 5.37 & 12.3 & 4.6 \\
\hline $\mathrm{A}_{1} \mathrm{~B}_{2} \mathrm{C}_{1}$ & 4.1 & 3.23 & 0.54 & 0.2 & 2.9 & 1.45 & 4.35 & 3.98 & 4.16 & 4.1 & 12.3 & 4.1 \\
\hline $\mathrm{A}_{1} \mathrm{~B}_{2} \mathrm{C}_{2}$ & 4.1 & 3.35 & 0.54 & 0.28 & 2.9 & 1.57 & 4.35 & 3.9 & 4.16 & 4.1 & 12.3 & 4.5 \\
\hline $\mathrm{A}_{1} \mathrm{~B}_{2} \mathrm{C}_{3}$ & 4.1 & 3.96 & 0.54 & 0.36 & 2.9 & 1.79 & 4.35 & 4.20 & 4.16 & 4.97 & 12.3 & 5.3 \\
\hline $\mathrm{A}_{2} \mathrm{~B}_{1} \mathrm{C}_{1}$ & 4.1 & 3.19 & 0.54 & 0.18 & 2.9 & 0.95 & 4.35 & 4.4 & 4.16 & 4.3 & 12.3 & 4.3 \\
\hline $\mathrm{A}_{2} \mathrm{~B}_{1} \mathrm{C}_{2}$ & 4.1 & 3.33 & 0.54 & 0.23 & 2.9 & 0.95 & 4.35 & 4.25 & 4.16 & 4.51 & 12.3 & 4.2 \\
\hline $\mathrm{A}_{2} \mathrm{~B}_{1} \mathrm{C}_{3}$ & 4.1 & 3.62 & 0.54 & 0.24 & 2.9 & 1.06 & 4.35 & 4.30 & 4.16 & 4.77 & 12.3 & 5 \\
\hline $\mathrm{A}_{2} \mathrm{~B}_{2} \mathrm{C}_{1}$ & 4.1 & 3.28 & 0.54 & 0.21 & 2.9 & 1.34 & 4.35 & 4.23 & 4.16 & 4.50 & 12.3 & 4.2 \\
\hline $\mathrm{A}_{2} \mathrm{~B}_{2} \mathrm{C}_{2}$ & 4.1 & 3.32 & 0.54 & 0.25 & 2.9 & 1.49 & 4.35 & 4.50 & 4.16 & 4.46 & 12.3 & 4.4 \\
\hline $\mathrm{A}_{2} \mathrm{~B}_{2} \mathrm{C}_{3}$ & 4.1 & 3.38 & 0.54 & 0.32 & 2.9 & 1.66 & 4.35 & 4.21 & 4.16 & 5.1 & 12.3 & 5.3 \\
\hline
\end{tabular}

Final $=$ Last day of storage period i.e. shelf life of each treatment, $A_{1} B_{1} C_{1}=7$ days, $\mathrm{A}_{1} \mathrm{~B}_{1} \mathrm{C}_{2}=7$ days, $\mathrm{A}_{1} \mathrm{~B}_{1} \mathrm{C}_{3}=$ ll days, $\mathrm{A}_{1} \mathrm{~B}_{2} \mathrm{C}_{1}=9$ days, $\mathrm{A}_{1} \mathrm{~B}_{2} \mathrm{C}_{2}=11$ days, $\mathrm{A}_{1} \mathrm{~B}_{2} \mathrm{C}_{3}=13$ days, $\mathrm{A}_{2} \mathrm{~B}_{1} \mathrm{C}_{2}=12$ days, $\mathrm{A}_{2} \mathrm{BC}_{2}=10$ days, $\mathrm{A}_{2} \mathrm{~B}_{2} \mathrm{C}_{3}=17$ days, $\mathrm{A}_{2} \mathrm{~B}_{2} \mathrm{C}_{1}=9$ days, $\mathrm{A}_{2} \mathrm{~B}_{2} \mathrm{C}_{2}=$ 12 days, $\mathrm{A}_{2} \mathrm{~B}_{2} \mathrm{C}_{3}=14$ days

It is clear from the Fig. 1 that the trend of percent weight loss was increasing with the advancement of storage period. It was the highest in fruits of non-treated and without packaging, closely followed by those of non-treated and packed in gunny bag, while the lowest in the fruit treated with chlorine and packed in perforated polyethylene bag. 


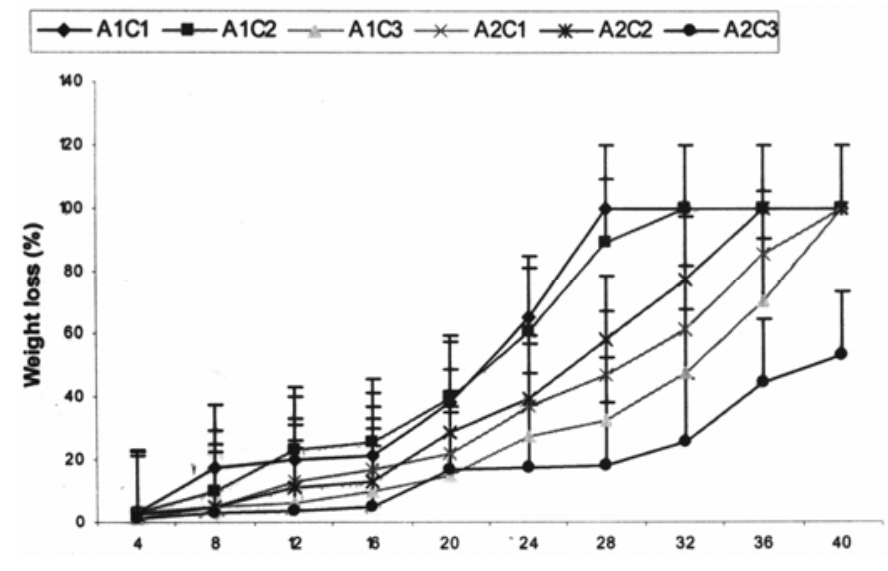

Days

Fig. 1 weight loss of tomato at different storage perid (ambient teperature)

Fig 2 shows the disease incidence of tomato at different storage periods at ambient conditions. On the 8th day of storage period, diseases were observed in all treatments except tomato treated with chlorine, without packaging and packed in perforated poly bag. From 20th day, diseases were observed in the tomato, treated with chlorine and packed in perforated polyethylene bag. The percent disease incidence was found to be the highest in fruits with non-treated and without packaging, closely followed by the fruit non-treated and packed in gunny bag.

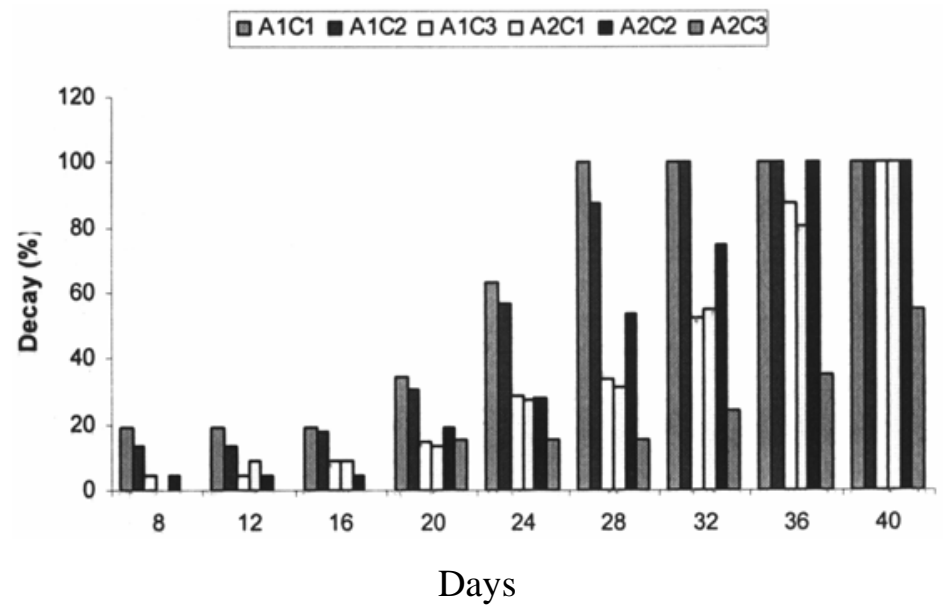

Fig. 1. Decay of tomato at different storage period (ambient teperature).

At 40th day, diseases damaged only $54.76 \%$ fruit when it was treated with chlorine and packed in perforated poly bag, while all other treatments were spoiled $100 \%$ by diseases. It was observed that Alterneria spp., Cercospora spp. Colletotrichum spp., Aspergillus spp.and Fusarium spp. were responsible for 
diseases. It is somewhat similar to postharvest diseases symptoms of tomato reported by Sommer et al. (1992).

\section{Conclusion}

It can be concluded from the above results that shelf life of tomato could be extended upto 17 days without excessive deterioration in quality by treating the fruits with chlorine, packed in perforated polyethylene bag and kept at ambient temperature as compared to control for 7 days only.

\section{References}

AOAC. 1975. Official Methods of Analysis (Association of Official Analytical Chemist. Washington, DC.), XIIed.

Aworth, O.C. and A.O. Olorunda. 1981. Towards reducing postharvest losses of perishable fruits and vegetables in Nigeria. Proceding of the National Conference in Agriculture. Port Harcourt, Nigeria.

Amiruzzaman, M. 2000. Postharvest Technology/Management (vegetables). A consultancy report. AVRDC-USAID Bangladesh Project. pp-193.

Badgujar, C.D., K.E. Lawande. and P.N. Kale. 1987. Polythene packaging for increasing shelf life in brinjal fruits. Current Research Reporter. Mahatma Phule Agril. Univ., 3:2, 22-25; 2 ref.

Barooah, S. 1993. Vegetable Growing in India, Kalyani Publishers, Ludhiana. New Delhi, India. pp-93.

Bose, T. K. and M. G. Som. 1986. Vegetable crops in India. Naya Prokash, 206 Bidhan Saroni, Calcutta 700006, India. pp-759.

Giraldo, L.F., R.A. Forero., C.R. Salazar and R. Torres. 1977. The effect of packaging and potassium permanganate on the storage of tomatoes under room conditions. Ravista Inst. Collanbiano Agropecuario, 12(4): 393-405. (Hort, Abstr. 49:4289).

Kader, A.A., D. Zagory and E.L. Kervel. 1989. Modified atmosphere packaging of fruits and vegetables. Critical Review in Food Science and Nutrition 28: 1-30,

Mondal, M. F. 2000. Production and storage of fruits (in Bangla). Published by Mrs. Afia Mondal. BAU Campus, Mymensingh-2202. pp-312.

Ruth Ben, Arie and Susanlurie. 1986. Prolongation of fruit life after harvest. In hand book of fruit set and development. (Ed. Shaul P. Monselise) CRC press.

Salunkhe, D.K., H.R. Bolin and N.R. Reddy.1991. Storage, processing and nutritional quality of fruits and vegetables (2d ed.). CRC press, Boston, USA. p 147-162.

Sommer, N. F., R. J. Fortlage., and D.C. Edwards, 1992. Postharvest diseases of selected commqdities. In: Postharvest technology of horticultural crops.A.A.Kader(eds). University of California, Division of agriculture and natural resources, USA. pp-136. 